\title{
UPAYA MENINGKATKAN BELAJAR PKn MATERI KEBEBASAN BERORGANISASI MELALUI METODE MIND MAPPING BAGI SISWA KELAS V SD NEGERI BABATAN TAHUN PELAJARAN 2016/2017
}

\author{
Puji Rahayu \\ SDN Babatan Gresik \\ rahayupuji1@gmail.com
}

\begin{abstract}
ABSTRAK
Penelitian ini bertujuan untuk meningkatkan prestasi belajar siswa kelas $\mathrm{V}$ semester 2 SD Negeri Babatan Balongpanggang tahun pelajaran 2016/2017 dalam pembelajaran PKn materi Kebebasan Berorganisasi melalui penggunaan metode mind-mapping. Penelitian ini dilakukan di SD Negeri Babatan Balongpanggang UPTD Pendidikan Kecamatan Balongpanggang, Kabupaten Gresik pada semester 2 tahun pelajaran 2016/2017 selama 1 (satu) bulan. Subjek penelitian adalah siswa kelas V Semester 2 di SD Negeri Babatan Balongpanggang UPTD Pendidikan Kecamatan Balongpanggang, Kabupaten Gresik tahun pelajaran 2016/2017 yang terdiri dari 18 orang siswa. Prosedur penelitian dalam penelitian tindakan ini pada intinya mengacu pada desain penelitian yang digunakan, yaitu perencanaan; pelaksanaan; observasi; dan refleksi hasil tindakan. Penelitian ini menyimpulkan bahwa Penggunaan pembelajaran mind-mapping dapat meningkatkan prestasi belajar siswa dalam pembelajaran PKn materi "Kebebasan Berorganisasi" bagi siswa kelas V semester 2 SD Negeri Babatan Balongpanggang, Gresik tahun pelajaran 2016/2017. Hal ini ditunjukkan dengan meningkatnya nilai rata-rata hasil belajar dan tingkat ketuntasan belajar siswa pada setiap siklus tindakan yang dilakukan. Nilai rata-rata prestasi belajar siswa pada kondisi awal adalah sebesar 67.78. Nilai rata-rata tersebut mengalami peningkatan menjadi 72.00 pada akhir tindakan Siklus I, dan meningkat menjadi sebesar 77.56 pada akhir tindakan Siklus II. Ditinjau dari penguasaan penuh secara klasikal, ketuntasan belajar siswa mengalami peningkatan dari 55.56\% pada kondisi awal meningkat menjadi $61.11 \%$ pada akhir tindakan Siklus I, kemudian meningkat menjadi $94.44 \%$ pada akhir tindakan pembelajaran Siklus II.
\end{abstract}

Kata Kunci: Prestasi belajar, pembelajaran PKn, metode mind mapping.

\section{ABSTRACT}

This study aims to improve the achievement of students of class $V$ semester 2 SD Negeri Babatan Balongpanggang academic year 2016/2017 in learning PKn material Freedom Organize through the use of mind-mapping method. This research was conducted at SD Negeri Babatan Balongpanggang UPTD Education of Kecamatan Balongpanggang, Gresik Regency in second semester of academic year 2016/2017 for a month. The subjects of the study were V students of Semester 2 at SD Negeri Babatan Balongpanggang UPTD Pendidikan Kecamatan Balongpanggang, Gresik Regency in the academic year 2016/2017 consisting of 18 students. The research procedure in this action research essentially refers to the research design used, namely planning; implementation; observation; and reflection on the result of action. This study concludes that the use of mind-mapping learning can improve students' learning achievement in learning Civics material "Freedom of Organization" for students of class V semester 2 SD Negeri Babatan Balongpanggang, Gresik academic year 2016/2017. This is indicated by the increase in the average value of learning outcomes and student's level of completeness in every cycle of action performed. The average value of student achievement in the initial conditions is 67.78. The average value increased to 72.00 at the end of Cycle I action, and increased to 77.56 at the end of Cycle II. Judging from the full mastery of the classical, students' learning mastery increased from $55.56 \%$ in the initial conditions increased to $61.11 \%$ at the end of Cycle I action, then increased to 94.44\% at the end of Cycle II learning action.

Keywords: Learning achievement, Civics learning, mind mapping method. 


\section{PENDAHULUAN}

Peranan pendidikan dianggap sangat penting untuk menghasilkan sumber daya manusia yang berkualitas. Tanpa pendidikan, manusia akan terbelakang dan sulit berkembang. Pendidikan sifatnya mutlak dalam kehidupan seseorang, keluarga, maupun bangsa dan Negara. Maju mundurnya suatu bangsa banyak ditentukan oleh maju mundurnya suatu pendidikan di Negara tersebut. Kualitas pendidikan yang tinggi diperlukan untuk menciptakan kehidupan yang cerdas, damai, terbuka, demokratis dan mampu bersaing.

Mata Pelajaran Pendidikan Kewarganegaraan merupakan salah satu mata pelajaran pokok di Madrasah Ibtidaiyah yang memfokuskan pada pembentukan karakter siswa yang memahami dan mampu melaksanakan hak-hak dan kewajibannya untuk menjadi warga Negara yang baik, cerdas, terampil, dan berkarakter yang diamanatkan oleh Pancasila dan UUD 1945, serta memfokuskan pada pembentukan diri yang beragam dari segi agama, sosiokultural, bahasa, usia dan suku bangsa.

Sekolah Dasar sebagai salah satu lembaga pendidikan formal merupakan wadah untuk mengaktualisasikan tujuan tersebut melalui pembelajaran sehingga diharapkan dapat menghasilkan manusia yang beriman dan bertaqwa kepada Tuhan Yang Maha Esa serta berguna bagi Bangsa dan Negaranya.

Pendidikan Kewarganegaraan, oleh sebagian anak sering kali dianggap sebagai mata pelajaran yang membosankan, yang hanya mementingkan hafalan semata dan kurang menekankan pada aspek penalaran. Hal ini menyebabkan rendahnya minat anak untuk belajar PKn. Selain itu cara guru dalam penyampaian materi masih mengandalkan cara-cara lama yang kurang melibatkan keaktifan siswa dalam kegiatan pembelajaran.

Banyak faktor yang menyebabkan hasil belajar PKn siswa rendah yaitu faktor internal dan eksternal dari siswa. Faktor internal antara lain: motivasi belajar, intelegensi, kebiasaan dan rasa percaya diri. Sedangkan faktor eksternal adalah faktor yang terdapat di luar siswa, seperti : guru sebagai pembina kegiatan belajar, strategi pembelajaran, sarana dan prasarana, kurikulum dan lingkungan.

Pembelajaran Pendidikan

Kewarganegaaran yang ada di $S D$ Negeri Babatan Kecamatan Balongpanggang Kabupaten Gresik, memerlukan model pembelajaran yang mampu menciptakan suasana pembelajaran yang menarik serta dapat meningkatkan hasil belajar siswa. Salah satu usaha yang dapat dilakukan adalah dengan memilih model pembelajaran yang dapat memberikan kesempatan seluas- 
luasnya kepada siswa untuk berkembang.

Pada mata pelajaran Pendidikan Kewarganegaraan, siswa kelas V di $S D$ Negeri Babatan Kecamatan Balongpanggang Kabupaten Gresik masih kurang memahami materi, bisa jadi hal ini dikarenakan penggunaan metode yang belum cocok, dengan menggunakan metode ceramah kurang efektif, dan juga disebabkan karena masih usia anak-anak. Kekurangan itu terbukti dari hasil tes tertulis yang nilainya masih kurang dari rata-rata yang melebihi KKM. Oleh karena itu disini peneliti mempunyai inisiatif untuk merubah metode dari metode ceramah ke dalam metode Mind Mapping.

Penggunaan metode Mind Mapping, diharapkan akan dapat merubah dan meningkatkan keberhasilan pelajaran Pendidikan Kewarganegaraan kelas V di SD Negeri Babatan Kecamatan Balongpanggang Kabupaten Gresik. Berdasar kondisi tersebut, maka peneliti mengadakan penelitian dengan judul " Upaya Meningkatkan Prestasi Belajar Pendidikan Kewarganegaraan Materi Kebebasan Berorganisasi melalui metode Mind Mapping pada siswa kelas V SD Negeri Babatan Kecamatan Balongpanggang Kabupaten Gresik.Tahun Pelajaran 2016/2017 “

\section{METODOLOGI PENELITIAN}

\section{Tujuan Penelitian}

Tujuan dari penelitian ini adalah untuk : 
1. Jenis Penelitian

Penelitian ini menggunakan jenis Penelitian Tindakan Kelas (classroom action research). Penelitian Tindakan Kelas (PTK) merupakan penelitian tindakan (action research) yang dilakukan dengan tujuan memperbaiki mutu praktik pembelajaran dikelas.

2. Pendekatan Penelitian

Penelitian tindakan kelas mempunyai fokus terapan, di mana peneliti mengumpulkan data berdasarkan pada metode kuantitatif maupun metode kualitatif atau bahkan keduaduanya.

Pendekatan penelitian yang digunakan dalam penelitian ini adalah pendekatan kualitatif berdasar pada data kuantitaif. Analisi data dalam penelitian ini adalah analisis data secara induktif.

Analisis data kualitatif bersifat induktif yaitu suatu analisis berdasarkan data yang diperoleh, selanjutnya dikembangkan pola hubungan tertentu atau menjadi hipotesis. Hipotesis yang dirumuskan berdasarkan data tersebut, selanjutnya dicarikan data lagi secara berulang-ulang sehingga selanjutnya dapat disimpulkan apakah hipotesis tersebut diterima atau ditolak berdasarkan data terkumpul. Berdasarkan data-data yang dikumpulkan secara berulangulang dengan teknik triangulasi, ternyata hipotesis diterima, maka hipotesis tersebut berkembang menjadi teori.

3. Subyek dan Obyek Penelitian

Subyek dari penelitian ini adalah siswa-siswi kelas $\mathrm{V}$ di SD Negeri Babatan Kecamatan Balongpanggang Kabupaten Gresik yang terdiri atas 22 siswa. 13 siswa laki-laki dan 9 siswa perempuan.

Obyek dari penelitian ini adalah keseluruhan proses dan hasil pelaksanaan pembelajaran PKn kelas V SD Negeri Babatan Kecamatan Balongpanggang Kabupaten Gresik melalui metode Mind Mapping.

\section{Tempat dan Waktu}

Penelitian ini dilaksanakan pada bulan Pebruari 2017, Semester II Tahun Pelajaran 2016/2017. Tempat penelitian adalah kelas $V$ SD Negeri Babatan Kecamatan Balongpanggang Kabupaten Gresik.

\section{Teknik Pengumpulan Data}

Teknik pengumpulan data yang akan penulis gunakan adalah sebagai berikut

1. Metode Observasi

Metode observasi, secara sederhana berarti pengamatan dengan tujuan tertentu dari kegiatan keseharian manusia dengan menggunakan panca indera mata sebagai alat bantu utamanya selain panca indera lainnya seperti telinga, penciuman, mulut, kulit. Sesungguhnya yang dimaksud dengan metode 
observasi adalah metode pengumpulan data yang digunakan untuk menghimpun data penelitian melalui pengamatan dan pengindraan.

Observasi ini dilakukan selama proses penelitian berlangsung, guna mengetahui prestasi belajar siswa dalam pembelajaran PKn dengan menggunakan metode Mind Mapping.

2. Metode Wawancara

Metode wawancara atau interview adalah suatu cara pengumpulan data yang digunakan untuk memperoleh informasi langsung dari sumbernya.

Wawancara adalah percakapan dengan maksud tertentu. Percakapan ini dilakukan oleh dua pihak, yaitu pewawancara (interviewer) yang mengajukan pertanyaan dan terwawancara (interviewee) yang memberikan jawaban atas pertanyaan.

Metode ini digunakan untuk mewawancarai siswa maupun guru PKn kelas $\mathrm{V}$ pada saat proses pembelajaran, yaitu dilakukan dua kali pada siklus I dan siklus II, serta dilakukan untuk mewawancarai kepala madrasah dan staf guna mencari informasi mengenai keadaan madrasah.

3. Metode Dokumentasi

Metode dokumentasi adalah alat pengumpulan data yang digunakan untuk mencari informasi mengenai hal-hal yang berupa catatan. Metode dokumentasi adalah metode pengumpulan data yang dilakukan dengan cara memperhatikan tulisan, tempat, atau orang.

Metode ini penulis gunakan untuk memperoleh data tentang gambaran umum sekolah, seperti letak geografis, struktur organisasi, dan hal-hal yang berkaitan dengan sekolah dan proses pembelajarannya. Juga digunakan untuk memperoleh gambaran ketika proses pembelajaran kebebasan berorganisasi dengan metode Mind Mapping.

4. Tes Hasil Belajar

Tes adalah serangkaian pertanyaan atau latihan yang digunakan untuk mengukur keterampilan, pengetahuan inteligensi, kemampuan atau bakat yang dimiliki oleh setiap individu atau kelompok.

Tes digunakan untuk mengukur kemampuan siswa sebelum dan sesudah tindakan. Tes awal diberikan untuk mengetahui kemampuan siswa sebelum memahami suatu materi, sedangkan tes akhir diberikan untuk mengetahui sampai sejauh mana siswa memahami materi yang telah diberikan. Tes ini digunakan untuk mendapatkan data tentang prestasi belajar siswa.

\section{Desain Penelitian}

Pada prinsipnya diterapkannya penelitian tindakan kelas atau 
classroom action research

dimaksudkan untuk mengatasi suatu permasalahan yang terdapat di dalam kelas.

Sebagai salah satu penelitian yang dimaksudkan untuk memecahkan permasalahan di dalam kelas, menyebabkan terdapatnya beberapa model atau desain yang dapat diterapkan. Desain tersebut di antaranya: 1) Model Kurt Lewin, 2) Model Kemmis \& McTaggart, 3) Model Dave Ebbutt, 4) Model John Elliot, 5) Model Hopkins, dan masih ada beberapa model lain, yang pada prinsipnya

merupakan

pengembangan dari model yang ada.

Penelitian ini menggunakan metode penelitian tindakan kelas dengan menggunakan desain penelitian dari Model Kemmis dan Mc Taggart. Desain penelitian tindakan kelas ini terdiri dari empat tahap, yaitu: perencanaan (planning), tindakan (action), pengamatan (observing), dan refleksi (reflecting). Keempat tahapan tersebut dilakukan dalam siklus berulang. Adapun desain dari penjelasan masing-masing tahap tersebut sebagai berikut

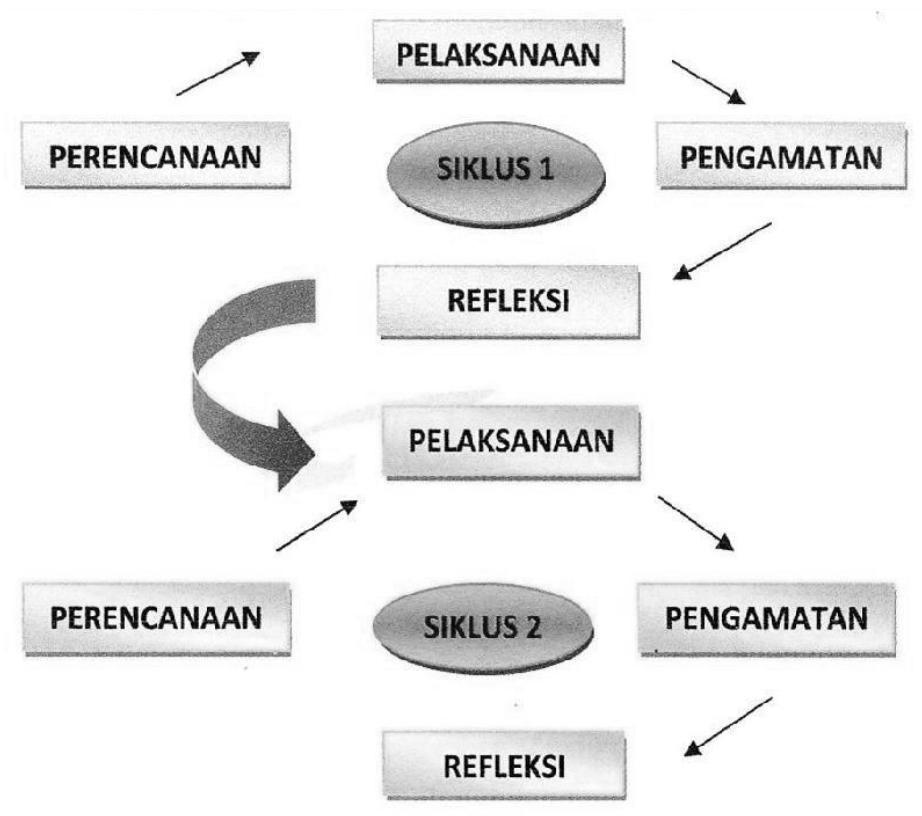

Gambar 1. Desain Penelitian Tindakan Kelas

Hubungan antara keempat komponen tersebut menunjukkan sebuah siklus (putaran) berkelanjutan dan berulang. Siklus inilah yang sebenarnya menjadi salah satu ciri utama dari penelitian tindakan kelas, yaitu bahwa penelitian tindakan kelas harus dilaksanakan dalam bentuk siklus, bukan satu kali tindakan saja. Putaran atau siklus tersebut berulang terus sampai mampu memecahkan masalah yang dihadapi.

Pelaksanaan PTK minimal dilakukan dalam dua kali siklus. 
Adapun pelaksanaan PTK dalam skripsi ini dilakukan dua kali siklus. Dalam setiap siklus dilakukan satu tindakan diwujudkan dalam kegiatan pembelajaran selama satu kali pertemuan yang lamanya $2 \times 35$ menit. Pelaksanaan PTK dimulai dengan siklus pertama.

Apabila dalam siklus pertama sudah menunjukkan perbaikan atau keberhasilan dan tidak ada hambatan dari kegiatan yang dilakukan maka peneliti menentukan rancangan siklus kedua. Kegiatan pada siklus kedua dapat berupa kegiatan yang sama pada siklus pertama, tetapi pada umumnya kegiatan pada siklus kedua mempunyai tambahan perbaikan dari tindakan terdahulu. Jika peneliti merasa belum puas dengan keberhasilan pada siklus pertama dan kedua maka boleh melanjutkan ke siklus berikutnya dan seterusnya sampai guru dan peneliti merasa puas dengan penelitian tindakan kelas yang dilakukan.

\section{Prosedur Penelitian}

Penelitian ini bertujuan untuk meningkatkan prestasi belajar PKn materi kebebasan berorganisasi melalui metode Mind Mapping. Untuk lebih rincinya perencanaan penelitian tindakan kelas ini sebagai berikut :

\section{Siklus I}

1. Perencanaan

a. Sebelum penelitian tindakan kelas dilakukan, peneliti mengadakan observasi serta melakukan wawancara dengan guru PKn untuk berdiskusi permasalahan yang terjadi sehubungan dengan pembelajaran PKn. Solusi untuk memperbaiki masalah yang didiskusikan adalah meningkatkan prestasi belajar PKn tentang kebebasan berorganisasi serta metode Mind Mapping.

b. Memberikan informasi cara melakukan tindakan sesuai dengan rancangan kepada guru yang membantu pelaksanaan PTK.

c. Membuat Rencana Pelaksanaan Pembelajaran (RPP) mengenai materi yang telah ditentukan.

d. Mempersiapkan fasilitas dan sarana pendukung yang diperlukan.

e. Mempersiapkan cara observasi sekaligus lembar observasi.

2. Pelaksanaan Tindakan

Tindakan dalam penelitian tindakan kelas mencakup prosedur yang akan dilakukan, serta proses perbaikan yang akan dilakukan. Pada tahap ini, rencana pembelajaran yang telah disusun oleh guru bersama peneliti dipergunakan sebagai dasar dalam menyelenggarakan pembelajaran.

Pada fase ini, guru dan peneliti melaksanakan pembelajaran kebebasan berorganisasi melalui metode Mind Mapping pada mata pelajaran Pendidikan Kewarganegaraan 
sesuai rencana yang telah dibuat dalam RPP.

a. Observasi

Observasi dilaksanakan bersamaan dengan proses pembelajaran. Observasi yang dilakukan adalah mengamati setiap tindakan yang meliputi: aktivitas guru, interaksi siswa dengan guru, interaksi siswa dengan siswa atau semua fakta yang ada selama proses pembelajaran berlangsung. Sementara kegiatan berlangsung, peneliti mengamati perilaku dan perubahan yang terjadi pada siswa dan mencatatnya. Fungsi observasi adalah merekam semua aktivitas dan kemampuan yang ditunjukkan siswa selama kegiatan pembelajaran berlangsung.

b. Refleksi

Pada tahap ini, kegiatan yang dilakukan adalah menguraikan tentang prosedur analisis terhadap hasil pemantauan dan refleksi tentang proses dan dampak tindakan perbaikan yang dilakukan, serta kriteria dan rencana tindakan pada siklus berikutnya.

Hasil catatan pemantauan penelitidan catatan guru merupakan bahan untuk melakukan refleksi. Peneliti bersama guru membahas dampak yang ditangkap dan membandingkan dengan keadaan sebelum tindakan. Hasil refleksi digunakan sebagai acuan pelaksanaan tindakan kelas pada siklus selanjutnya. Jika hasil yang diinginkan belum tercapai, maka perbaikan akan terus dilakukan sampai memperoleh hasil yang maka perbaikan akan terus dilakukan sampai memperoleh hasil yang diinginkan.

\section{Siklus II}

Siklus II ini merupakan perbaikan dari siklus I. Siklus II dilakukan untuk menutupi kekurangan-kekurangan yang terdapat pada siklus I. Adapun tahapan-tahapan pada siklus II ini sama dengan tahapan pada siklus I hanya saja ditekankan dengan tujuan untuk perbaikan dari siklus I.

Tahapan-tahapan yang dilakukan pada siklus II adalah:

1. Perencanaan

Kegiatan yang dilakukan pada tahap perencanaan ini adalah menyusun rancangan kegiatan pembelajaran (RPP) yang akan dilaksanakan sebagaimana pada siklus I.

2. Pelaksanaan tindakan

Pelaksanaan tindakan yang dilakukan pada tahap ini adalah melaksanakan rencana pelaksanaan pembelajaran yang telah dibuat pada siklus II, yaitu memperbaiki pembelajaran kebebasan berorganisasi Mind Mapping pada mata pelajaran PKn 
kelas $\mathrm{V}$ SD Negeri Babatan Kecamatan Balongpanggang Kabupaten Gresik

3. Observasi

Peneliti mengamati kegiatan pembelajaran pada siklus II untuk mengetahui apakah sudah ada kemajuan pada proses pembelajaran dari siklus I ke siklus II.

\section{Refleksi}

Seluruh data dan informasi yang telah diperoleh kemudian sebagai landasan untuk menentukan apakah tujuan yang diharapkan sudah tercapai atau belum.

\section{Teknik Analisis Data}

Analisis data yang dilakukan dalam penelitian ini adalah menggunakan analisis data deskriprif kualitatif. Analisis data dalam penelitian kualitatif, dilakukan pada saat pengumpulan data berlangsung, dan setelah selesai pengumpulan data dalam periode tertentu.

Miles dan Huberman
mengemukakan bahwa aktivitas
dalam analisis data kualitatif
dilakukan secara interaktif dan
berlangsung secara terus menerus
sampai tuntas, sehingga datanya
sudah jenuh. Aktivitas dalam analisis
data, yaitu data reduction, data
display, dan conclusion drawing /
verification.

\section{Data Reduction (Reduksi Data)}

Memilih yang penting, membuat kategori (huruf besar, huruf kecil, angka), membuang yang tidak dipakai. Pada mulanya diidentifikasikan adanya satuan yaitu bagian terkecil yang ditemukan dalam data. Data yang diperoleh dari lapangan jumlahnya cukup banyak, untuk itu maka perlu dicatat secara teliti dan rinci. Mereduksi data berarti merangkum, memilih hal-hal yang pokok, memfokuskan pada hal-hal yang penting, dicari tema dan polanya. Dengan demikian data yang telah direduksi akan memberikan gambaran yang lebih jelas dan mempermudah peneliti untuk melakukan pengumpulan data selanjutnya, dan mencarinya bila diperlukan.

\section{Data Display (Penyajian Data)}

Pada tahap ini penyajian data berfungsi untuk menyajikan data dalam bentuk tabel dengan tujuan data agar lebih mudah dibaca dan dipahami.

Untuk mengetahui peningkatan prestasi belajar siswa akan dilihat dari nilai pre test dan post test. Untuk menghitung nilai rata-rata prestasi belajar siswa menggunakan rumus :

$$
\frac{P \times f \times 100 \%}{N}
$$

Keterangan:

$\mathrm{P}$ : Angka persentase yang dicari

$f$ : Frekuensi yang sedang dicari persentasenya (frekuensi jawaban responden).

$\mathrm{N}$ : Number of Case jumlah frekuensi / banyaknya individu) 
3. Conclusion Drawing / Verification (Pengambilan Kesimpulan)

Data yang diperoleh, kemudian diambil kesimpulan, apakah tujuan dari penelitian tersebut sudah mencapai yang ditargetkan atau belum. Jika ternyata dalam penelitian tersebut persentasenya belum tercapai sesuai target, maka perlu dilakukan tindakan selanjutnya, jika setelah dilakukan tindakan selanjutnya persentase sudah tercapai maka penelitian dapat dihentikan.

\section{HASIL}

$$
\text { PENELITIAN }
$$

DAN

\section{PEMBAHASAN}

\section{Deskripsi Kondisi Awal}

Kondisi awal tindakan merupakan hasil pengamatan terhadap kondisi pembelajaran PKn pada siswa di kelas V SD Negeri Babatan Balongpanggang Kabupaten Gresik pada semester 2 tahun pelajaran 2016/2017. Data refleksi diperoleh dari hasil tes ulangan harian.

Berdasarkan hasil tes ulangan harian pada tabel di atas, dapat diketahui nilai terendah yang diperoleh siswa adalah 60.0 dan nilai tertinggi adalah sebesar 76.0. Nilai rata-rata kelas adalah sebesar 67.78 . Nilai rata-rata yang diperoleh siswa tersebut < KKM yang ditetapkan dengan $K K M \geq 70.00$. Berdasarkan hal tersebut maka secara klasikal siswa kelas V SD Negeri Babatan Balongpanggang Kabupaten Gresik belum mencapai ketuntasan belajar
PKn pada materi "Kebebasan Berorganisasi".

Ditinjau dari ketuntasan belajar, jumlah siswa yang sudah mencapai ketuntasan belajar dengan KKM $\geq$ 70.00 baru mencapai $55.56 \%$. Hal ini dapat diartikan bahwa dari 18 orang siswa yang ada di kelas tersebut, jumlah siswa yang sudah memperoleh nilai $\geq 70.00$ dalam pembelajaran PKn baru mencapai 10 orang siswa (55.56\%). Sisanya sebanyak 8 orang siswa atau $44.44 \%$ memperoleh nilai < 70.00. Data ketuntasan belajar siswa pada kondisi awal dapat disajikan pada tabel di bawah ini.

Tabel 2. Ketuntasan Belajar Siswa Kondisi Awal

\begin{tabular}{|c|c|c|c|}
\hline No & Ketuntasan & Jumlah & $\%$ \\
\hline 1 & Tuntas & 10 & $55.56 \%$ \\
\hline 2 & Tidak Tuntas & 8 & $44.44 \%$ \\
\hline Jumlah & 18 & $100,00 \%$ \\
\hline Nilai Rata-rata & \multicolumn{2}{|c|}{67.78} \\
\hline Nilai Tertinggi & \multicolumn{2}{|c|}{76.00} \\
\hline Nilai Terendah & \multicolumn{2}{|c|}{60.00} \\
\hline
\end{tabular}

Data tingkat ketuntasan belajar siswa pada kondisi awal tindakan dapat digambarkan ke dalam diagram sebagai berikut.

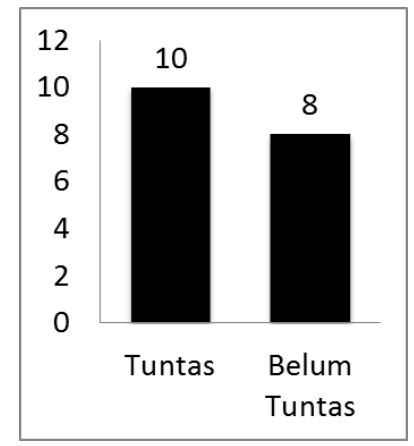

Gambar 2. Diagram Data Tingkat Ketuntasan Belajar Kondisi Awal 


\section{Deskripsi Tindakan Siklus I}

Perencanaan

tindakan

pembelajaran merupakan langkah operasional awal dari penelitian tindakan kelas yang disusun dengan mengacu pada hipotesis tindakan. Langkah awal yang dilakukan oleh guru dalam tindakan pembelajaran pada Siklus I meliputi antara lain: 1) Melakukan sosialisasi tentang metode pembelajaran mind-mapping yang digunakan kepada siswa kelas tindakan; 2) Menentukan materi pembelajaran pada tindakan Siklus I; 3) Menyusun skenario pembelajaran mind-mapping; 4) Menyiapkan sarana dan prasarana pembelajaran yang mendukung terlaksananya tindakan pembelajaran, dan lain sebagainya; 5) Mendeskripsikan secara jelas peran guru sebagai fasilitator pembelajaran tindakan, sebagai pengamat, dan sebagai evaluator; 6) Menyiapkan instrumen observasi berupa lembar pengamatan untuk mengukur motivasi belajar siswa (dampak proses pembelajaran) dan instrumen tes hasil belajar (dampak produk pembelajaran); dan 7) Melaksanakan simulasi pelaksanaan tindakan dan menguji keterlaksanaannya di lapangan.

Tes untuk mengukur hasil belajar siswa dilakukan pada hari Selasa, 25 Maret 2014. Hasil tes akhir pembelajaran tindakan Siklus I menunjukkan adanya peningkatan dalam hal tingkat ketuntasan belajar siswa dibandingkan pada kondisi awal.
Berdasarkan hasil tes yang dilaksanakan pada akhir tindakan Siklus I, dapat diketahui bahwa nilai terendah yang diperoleh siswa adalah sebesar 64.00, sedangkan nilai tertinggi adalah 80.00. Nilai rata-rata kelas yang diperoleh adalah sebesar 72.00. Mengingat bahwa nilai ratarata yang diperoleh siswa sudah melampaui KKM yang ditetapkan dengan $K K M \geq 70.00$, maka secara klasikal siswa kelas V Semester 2 SD Negeri Babatan Balongpanggang Kabupaten Gresik tahun pelajaran 2016/2017 sudah dianggap mencapai ketuntasan belajar dalam pembelajaran PKn.

Ditinjau dari ketuntasan belajar, jumlah siswa yang sudah mencapai ketuntasan belajar dengan KKM $\geq$ 70.00 adalah sebanyak 11 orang siswa atau $61.11 \%$. Sedangkan jumlah siswa yang belum mencapai ketuntasan belajar sebanyak 7 orang siswa atau $38.89 \%$.

Data ketuntasan belajar siswa pada tindakan Siklus I dapat disajikan ke dalam tabel berikut:

Tabel 3. Ketuntasan Belajar Siswa pada Tindakan Siklus I

\begin{tabular}{|c|c|c|c|}
\hline No & Ketuntasan & Jumlah & $\%$ \\
\hline 1. & Tuntas & 11 & $61.11 \%$ \\
\hline 2. & Tidak Tuntas & 7 & $38.89 \%$ \\
\hline \multicolumn{2}{|c|}{ Jumlah } & 18 & $100,00 \%$ \\
\hline Nilai Rata-rata & \multicolumn{2}{|c|}{72.00} \\
\hline Nilai Tertinggi & \multicolumn{2}{|c|}{80.00} \\
\hline Nilai Terendah & \multicolumn{2}{|c|}{64.00} \\
\hline
\end{tabular}

Data tingkat ketuntasan belajar siswa pada tindakan pembelajaran 
Siklus I dapat digambarkan ke dalam diagram sebagai berikut.

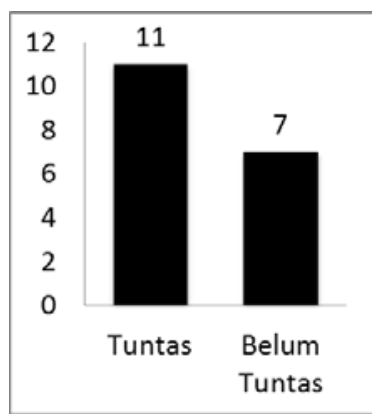

Gambar 3. Diagram Data Tingkat

Ketuntasan Belajar pada Tindakan

Siklus I

Berdasarkan hasil-hasil yang diperleh pada tindakan Siklus I, selanjutnya dapat diperoleh refleksi hasil tndakan pembelajaran mindmapping sebagai berikut:

1. Penggunaan metode pembelajaran pembelajaran mind-mapping pada tindakan Siklus I berhasil meningkatkan prestasi belajar siswa. Hal ini ditunjukkan dengan meningkatnya nilai rata-rata dan ketuntasan belajar siswa. Nilai ratarata hasil belajar siswa mengalami peningkatan dari sebesar 67.78 pada kondisi awal meningkat menjadi 72.00 pada akhir tindakan Siklus I. Ditinjau dari penguasaan penuh secara klasikal, tingkat ketuntasan belajar siswa mengalami peningkatan dari sebesar $55.56 \%$ pada kondisi awal, meningkat menjadi $61.11 \%$ pada akhir tindakan Siklus I.

2. Hal-hal yang masih belum berhasil dalam pembelajaran tindakan Siklus I adalah sebagai berikut: (a) Nilai rata-rata kelas yang diperoleh siswa sudah melampaui KKM yang ditentukan dengan KKM $\geq 70.00$. Meskipun demikian, indikator tingkat penguasaan penuh secara klasikal berupa $\geq 80.00 \%$ siswa sudah mencapai ketuntasan belajar dengan $\mathrm{KKM} \geq 70.00$ belum terpenuhi. Atas dasar hal tersebut maka diperlukan adanya beberapa perbaikan yang dilakukan pada tindakan Siklus II; (b) Ketrampilan siswa dalam membuat mindmapping masih perlu ditingkatkan. Atas dasar hal tersebut maka diperlukan perbaikan pembelajaran pada tindakan Siklus II.

\section{Deskripsi Tindakan Siklus II}

Berdasarkan hasil refleksi dan evaluasi pelaksanaan tindakan pembelajaran pada Siklus I, selanjutnya disusun rencana tindakan pembelajaran Siklus II sebagai upaya untuk meningkatkan dampak proses dan dampak produk dari tindakan pembelajaran yang lebih baik. Rencana pembelajaran tindakan ini merupakan hasil revisi dalam rangka perbaikan pembelajaran tindakan siklus I yang dinilai belum berhasil membawa siswa mencapai penguasaan kompetensi penuh. Beberapa upaya perbaikan yang akan dilaksanakan dalam tindakan pembelajaran Siklus II menyangkut upaya: 1) meningkatkan motivasi siswa dalam belajar; 2) meningkatkan kemandirian belajar siswa; 3) meningkatkan peran guru sebagai 
motivator dan fasilitator pembelajaran.

Pelaksanaan tindakan

pembelajaran pada Siklus II dilakukan dalam dua kali pertemuan, yaitu selama $4 \times 40$ menit. Pelaksanaan tindakan pembelajaran pada siklus ini sama dengan yang dilakukan pada siklus sebelumnya dengan disertai beberapa perbaikan. Pertemuan pertama tindakan pembelajaran Siklus II dilaksanakan pada hari Selasa, 08 Februari 2017. Pertemuan dilaksanakan selama $2 \times 40$ menit. Pertemuan II dilaksanakan pada hari Selasa, 15 Februari 2017. Pertemuan dilaksanakan selama $2 \times 40$ menit. Adapun kegiatan yang dilakukan adalah meneruskan presentasi kelompok yang pada pertemuan I belum menyampaikan hasil diskusi kelompok mereka.

Observasi diperoleh dari tes akhir tindakan Siklus II yang dilaksanakan pada hari Selasa, 22 Februari 2017. Hasil tes akhir pembelajaran tindakan Siklus ॥ menunjukkan adanya peningkatan dalam hal hasil belajar siswa. Berdasarkan hasil tes, dapat diketahui bahwa nilai terendah yang diperoleh siswa adalah sebesar 68.00, sedangkan nilai tertinggi adalah sebesar 88.0. Nilai rata-rata kelas yang diperoleh adalah sebesar 77.56. Data ketuntasan belajar siswa pada akhir tindakan pembelajaran Siklus II dapat disajikan pada tabel berikut.
Tabel 4. Ketuntasan Belajar Siswa pada Tindakan Siklus II

\begin{tabular}{|c|c|c|c|}
\hline No & Ketuntasan & Jumlah & \% \\
\hline 1. & Tuntas & 17 & $94.44 \%$ \\
\hline 2. & Tidak Tuntas & 1 & $5.56 \%$ \\
\hline \multicolumn{2}{|c|}{ Jumlah } & 18 & $100,00 \%$ \\
\hline Nilai Rata-rata & \multicolumn{2}{|c|}{77.56} \\
\hline Nilai Tertinggi & \multicolumn{2}{|c|}{88.00} \\
\hline Nilai Terendah & \multicolumn{2}{|c|}{68.00} \\
\hline
\end{tabular}

Data tingkat ketuntasan belajar siswa pada tindakan pembelajaran Siklus II dapat digambarkan ke dalam diagram berikut.

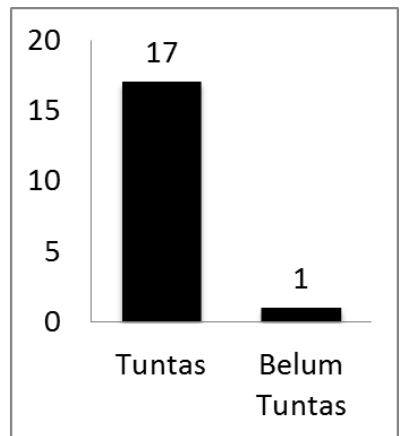

Gambar 4. Diagram Tingkat

Ketuntasan Belajar Siswa pada Tindakan Siklus II

Berdasarkan hasil perolehan tes akhir tindakan pembelajaran Siklus I dan tes tindakan pembelajaran Siklus II dapat diketahui bahwa nilai ratarata hasil belajar siswa siswa mengalami peningkatan, yaitu dari 72.00 pada akhir tindakan Siklus I menjadi 77.56 pada akhir tindakan pembelajaran Siklus II. Ditinjau dari tingkat penguasaan penuh secara klasikal, jumlah siswa yang sudah mencapai ketuntasan belajar dengan $K K M \geq 70.00$ mengalami peningkatan dari sebanyak 11 orang siswa (61.11\%) pada akhir tindakan Siklus I 
menjadi 17 orang siswa (94.44\%) pada akhir tindakan pembelajaran Siklus II.

Berdasarkan hasil-hasil yang diperloeh pada tindakan Siklus II, selanjutnya dapat diperoleh refleksi hasil tindakan sebagai berikut:

1. Implementasi pembelajaran mindmapping tindakan Siklus II berhasil meningkatkan prestasi belajar siswa dalam pembelajaran PKn materi "Kebebasan Berorganisasi" bagi siswa kelas $V$ SD Negeri Babatan Balongpanggang pada semester 2 tahun pelajaran 2016/2017. Hal ini ditunjukkan dengan meningkatnya nilai ratarata hasil belajar dan ketuntasan belajar siswa.

2. Hal-hal yang masih belum berhasil dalam pembelajaran tindakan Siklus II adalah masih adanya 1 orang siswa $(5.56 \%)$ yang belum mencapai ketuntasan belajar. Untuk itu siswa tersebut akan diberikan perlakuan khusus berupa pembelajaran remedial sehingga dapat mencapai ketuntasan belajar.

\section{Pembahasan Hasil Tindakan}

Metode pembelajaran mindmapping dapat meningkatkan prestasi belajar siswa dalam pembelajaran PKn materi "Kebebasan Berorganisasi" bagi siswa kelas V SD Negeri Babatan Balongpanggang pada semester 2 tahun pelajaran 2016/2017. Hal ini ditunjukkan dengan meningkatnya nilai rata-rata hasil belajar dan ketuntasan belajar siswa.
Prestasi belajar siswa pada kondisi awal masih cukup rendah. Hal ini ditunjukkan dengan nilai rata-rata hasil belajar yang diperoleh baru mencapai 67.78 atau masih < KKM yang ditetapkan dengan $\mathrm{KKM} \geq 70.00$. Ditinjau dari penguasaan penuh secara klasikal, jumlah siswa yang sudah mencapai ketuntasan belajar dengan KKM $\geq 70.00$ baru mencapai $55.56 \%$. Kurang optimalnya hasil belajar yang diperoleh siswa diduga disebabkan karena guru lebih banyak menggunakan metode ceramah sehingga siswa cenderung jenuh dan kurang berminat dalam mengikuti proses pembelajaran.

Berangkat dari keadaan tersebut, maka guru perlu melakukan perbaikan pembelajaran. Perbaikan pembelajaran yang dilakukan guru adalah dengan menerapkan metode mind mapping dalam pembelajaran PKn.

Perbaikan pembelajaran yang dilakukan guru pada tindakan Siklus I berhasil meningkatkan prestasi belajar siswa. Hal ini ditunjukkan dengan meningkatnya nilai rata-rata hasil belajar dari sebesar 67.78 pada kondisi awal, meningkat menjadi 72.00 pada akhir tindakan Siklus I. Peningkatan yang diperoleh pada tindakan Siklus I dipandang belum optimal. Hal ini dikarenakan belum terpenuhinya indikator penguasaan penuh secara klasikal berupa tercapainya $\geq 80.00 \%$ siswa mencapai ketuntasan belajar dengan KKM $\geq$ 70.00 . 
Atas dasar hal tersebut maka diperlukan perbaikan pembelajaran pada tindakan Siklus II. Adanya perbaikan yang dilakukan guru pada tindakan pembelajaran Siklus II mampu meningkatkan prestasi belajar siswa. Hal ini ditunjukkan dengan meningkatnya nilai rata-rata hasil belajar dan ketuntasan belajar siswa dibandingkan kondisi sebelumnya.

Nilai rata-rata hasil belajar siswa mengalami peningkatan dari sebesar 72.00 pada akhir tindakan Siklus I, meningkat menjadi 77.56 pada akhir tindakan Siklus II. Ditinjau dari penguasaan penuh secara klasikal, ketuntasan belajar siswa mengalami peningkatan, yaitu dari sebesar 61.11\% pada akhir tindakan Siklus I, meningkat menjadi sebesar $94.44 \%$ pada akhir tindakan Siklus II.

Peningkatan prestasi belajar siswa dari kondisi awal hingga akhir tindakan pembelajaran Siklus II selanjutnya dapat disajikan ke dalam tabel sebagai berikut:

Tabel 5. Prestasi Belajar Siswa dari Kondisi Awal hingga Akhir Tindakan Siklus II

\begin{tabular}{|c|c|c|c|c|c|c|c|}
\hline \multirow{2}{*}{ No } & \multirow{2}{*}{$\begin{array}{c}\text { Ketuntasan } \\
\text { Belajar }\end{array}$} & \multicolumn{2}{|c|}{ Kondisi Awal } & \multicolumn{2}{|c|}{ Siklus I } & \multicolumn{2}{|c|}{ Siklus II } \\
\hline & & Jmlh & $\%$ & Jmlh & $\%$ & Jmlh & $\%$ \\
\hline 1. & Tuntas & 10 & $55.56 \%$ & 11 & $61.11 \%$ & 17 & $94.44 \%$ \\
\hline 2. & Belum Tuntas & 8 & $44.44 \%$ & 7 & $38.89 \%$ & 1 & $5.56 \%$ \\
\hline & Jumlah & 18 & $100.00 \%$ & 18 & $100.00 \%$ & 18 & $100.00 \%$ \\
\hline & Nilai Rata-rata & \multicolumn{2}{|c|}{67.78} & \multicolumn{2}{|c|}{72.00} & \multicolumn{2}{|c|}{77.56} \\
\hline & Nilai Tertinggi & \multicolumn{2}{|c|}{76.00} & \multicolumn{2}{|c|}{80.00} & \multicolumn{2}{|c|}{88.00} \\
\hline & Nilai Terendah & \multicolumn{2}{|c|}{60.00} & \multicolumn{2}{|c|}{64.00} & \multicolumn{2}{|c|}{68.00} \\
\hline
\end{tabular}

\section{Data peningkatan}

ketuntasan belajar siswa dari kondisi awal hingga akhir tindakan Siklus II pada tabel di atas dapat disajikan ke dalam diagram sebagai berikut:

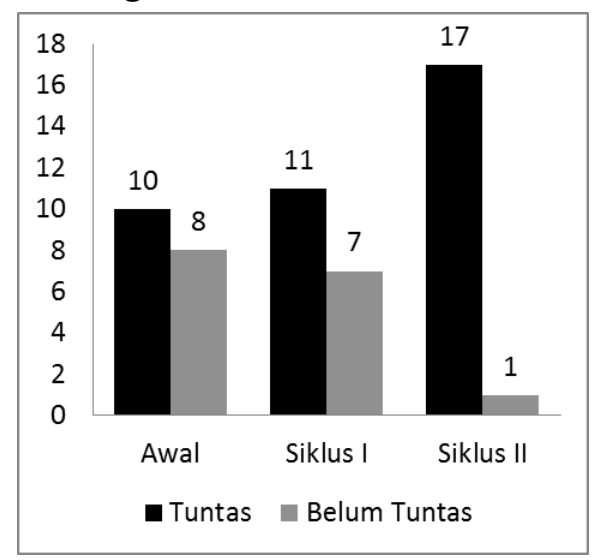

Gambar 6. Diagram Peningkatan ketuntasan Belajar Siswa dari Kondisi Awal hingga Akhir Tindakan Siklus II

Peningkatan prestasi belajar siswa menunjukkan bahwa dampak produk proses pembelajaran menjadi semakin jelas dan nyata. Hasil ini bila dikaji dari tingkat ketuntasan belajar siswa akan menjadi semakin jelas.

Langkah-langkah yang dilakukan guru dalam setiap siklus pembelajaran sudah sesuai dengan pandangan Richards, yaitu dilakukan dengan cara-cara sebagai berikut: (1) menetapkan 
dan mengkomunikasikan tujuan
pembelajaran pada awal
pembelajaran suatu unit; (2)
memberikan umpan balik
terhadap tujuan-tujuan tersebut;

(3) meninjau ulang tujuan pembelajaran secara terusmenerus dan sistematis; dan (4) memberikan umpan balik yang bersifat sumatif terhadap tujuan pembelajaran yang telah ditetapkan. Langkah tersebut ternyata mampu mendorong siswa untuk ikut terlibat aktif dalam kegiatan pembelajaran yang dilakukan.

Metode pembelajaran

mind-mapping yang digunakan guru mampu mendorong siswa untuk teribat dalam proses pembelajaran secara aktif. Aktivitas siswa dalam pembelajaran ditunjukkan dengan keterlibatan mereka dalam kerja kelompok maupun kerja individu.

\section{KESIMPULAN}

Berdasarkan analisis data dan pembahasan pada bab sebelumnya, penelitian tindakan kelas ini menyimpulkan sebagai berikut:

Penggunaan pembelajaran mind-mapping dapat meningkatkan prestasi belajar siswa dalam pembelajaran PKn materi "Kebebasan Berorganisasi" bagi siswa kelas V semester 2 SD Negeri Babatan Balongpanggang, Gresik tahun pelajaran 2016/2017. Hal ini ditunjukkan dengan meningkatnya nilai rata-rata hasil belajar dan tingkat ketuntasan belajar siswa pada setiap siklus tindakan yang dilakukan.

Nilai rata-rata prestasi belajar siswa pada kondisi awal adalah sebesar 67.78. Nilai rata-rata tersebut mengalami peningkatan menjadi 72.00 pada akhir tindakan Siklus I, dan meningkat menjadi sebesar 77.56 pada akhir tindakan Siklus II. Ditinjau dari penguasaan penuh secara klasikal, tingkat ketuntasan belajar siswa mengalami peningkatan pada setiap siklus tindakan yang dilakukan. Tingkat ketuntasan belajar siswa pada kondisi awal sebelum dilakukannya tindakan pembelajaran adalah sebesar 55.56\%. Tingkat ketuntasan belajar siswa pada akhir tindakan pembelajaran Siklus I mengalami peningkatan menjadi $61.11 \%$. Tingkat ketuntasan belajar siswa tersebut mengalami peningkatan menjadi 94.44\% pada akhir tindakan pembelajaran Siklus II.

\section{DAFTAR PUSTAKA}

Anni, Catharina Tri. 2005. Psikologi Pendidikan. Semarang : UPT MKK UNNES.

Arikunto, Suharsimi. 2010. Penelitian Tindakan: untuk Guru, Kepala Sekolah \& Pengawas. Yogyakarta: Aditya Media.

Buzan, Tony. 2008. Buku Pintar Mind Map. Jakarta : PT. Gramedia Pustaka Utama

Djamarah, S.B. 2010. Psikologi Belajar. Rineka Cipta: Jakarta. 
Indrawati dan Setiawan. 2009. Keterampilan Proses Sains. Bandung: Pusat Pengembangan Penataran Guru IImu Pengetahuan Alam.

Lexy J. Moeleng, M.A. Metodologi Penelitian Kualitatif (Edisi Revisi), (Bandung : Remaja Rosdakarya. 2014 )

Muhammad Ali, Guru Dalam Proses Belajar Mengajar (Bandung: Sinar Baru Algesindo, 2007)

Noer Farida. 2011. Efektivitas Pembelajaran Sistem Gerak Pada Manusia Melalui Pendekatan CTL Berbasis Mind Mapping Di SMP Negeri 2 Ungaran.

http:/lib.unnes.ac.id.8376/

Olivia, Femi. Gembira Belajar dengan Mind Mapping... (Jakarta : Elex Media Komputindo. 2008)

Poerwodarminto, Kamus Besar Bahasa Indonesia, (Jakarta : Balai Pustaka, 1996) Setiati Widihastuti, Fajar Rahayuningsih. Pendidikan Kewarganegaraan, (Jakarta : PT Pustaka Tiga Kelana. 2008)

Rusman. 2012. Model-model Pembelajaran. Jakarta: Radjawali Press.

Sadiman, Arief S. 2009. Media pendidikan: pengeratian, pengembangan, dan pemanfaatannya. Jakarta: Cv. Rajawali.

Sagala, S. 2011. Konsep dan Makna Pembelajaran. Alfabeta: Bandung.

Soetriono, Rita Hanafie. 2007. Filsafat IImu dan Metodologi Penelitian. Yogyakarta : Andi Offset.
Sudjana, Nana. 2012. Dasar-dasar Proses Belajar Mengajar. Bandung: Sinar Baru

Susilowati. 2013. "Integrated Science Worksheet Pembelajaran IPA SMP Dalam Kurikulum 2013" Makalah. Disampaikan dalam PPM "Diklat Pengembangan Student Worksheet ntegrated Science bagi Guru SMP/MTs di Kabupaten Sleman" Tanggal 24 Agustus 2013.

Suyatno. 2009. Menjelajah Pembelajaran Inovatif. Sidoarjo: Masmedia Buana Pustaka

Trianto. 2010. Mendesain Model Pembelajaran Inovatif Progresif. Jakarta: Kencana.

Winkel, WS. 2001. Psikologi Pengajaran. Jakarta: Gramedia.

Wiriaatmadja, Rochiati. 2006. Metode Penelitian Tindakan Kelas. Bandung: PT Remaja Rosdakarya. 